\title{
KERAGAAN TINGKAT PENGETAHUAN, SIKAP, DAN PERILAKU PETANI DALAM MENGGUNAKAN PUPUK ORGANIK PADA TANAMAN CABAI DI KABUPATEN JENEPONTO
}

\author{
Warda Halil, Yusmasari, dan Eka Triana Yuniarsih \\ Balai Pengkajian Teknologi Pertanian Sulawesi Selatan \\ Jl.Perintis kemerdekaan Km, 17,5 Sudiang Makassar \\ e-mail:warda69.halil@gmail.com
}

Received: 4 Agustus 2020; Accepted: 9 September 2020; Published: 25 Desember 2020

\begin{abstract}
ABSTRAK
Penggunaan pupuk kimia yang berlebihan dan tidak sesuai dosis pada tanaman cabai merupakan salah satu kebiasaan yang dilakukan petani. Hal tersebut mengakibatkan unsur hara dalam tanah menjadi kurus. Salah satu alternative yang dilakukan adalah dengan menggunakan pupuk organic yang dapat memperbaiki struktur tanah, mudah diperoleh dan tidak rumit cara pembuatannya serta ramah lingkungan. Penggunaan pupuk organic, tergantung dari pengetahuan, sikap dan ketrampilan petani. Tujuan penelitian ini untuk mengetahui tingkat pengetahuan, sikap dan perilaku petani dalam menggunakan pupuk organic. Metodologi dengan menggunakan wawancara langsung kepada petani dengan jumlah petani 60 orang. Metode analisis dengan menggunakan teknik scoring. Data dianalisis dengan menggunakan SPSS. Kesimpulan dari penelitian ini bahwa tingkat pengetahuan petani $(65 \%)$, sikap $(56,6 \%)$ dan perilaku $(51,67 \%)$ petani dalam penggunaan pupuk organic pada tanaman cabai di Kabupaten Jeneponto termasuk dalam kategori sedang.
\end{abstract}

Kata Kunci: Pengetahuan, sikap, perilaku, pupuk organik, cabai

\section{PENDAHULUAN}

Cabai merupakan salah satu komoditas hortikultura yang sangat penting. Hal ini disebabkan karena cabai dapat dimanfaatkan untuk berbagai keperluan baik yang berhubungan dengan kegiatan rumah tangga maupun sebagai industry dan ramuan obat tradisional. Selain itu secara umum cabai memiliki kandungan gizi dan vitamin diantaranya protein, lemak, karbohidrat, kalsium, vitamin A, B1 dan Vitamin C.

Menurut BPS, 2015. Sulawesi Selatan merupakan salah satu penghasil cabai di Indonesia, yaitu sekitar 23.780 ton/ha untuk cabai besar, sedangkan cabai rawit sebesar 26.571 ton/tahun. Menurut BPS 2010, Produktivitas cabai hanya 5,6 t/ha dibandingkan dengan potensinya dapat mencapai $12 \mathrm{t} / \mathrm{ha}$. Hal ini jauh lebih rendah dibandingkan produktivias dari Cina yang mencapai $21,5 \mathrm{t} / \mathrm{ha}$, Thailand $14,2 \mathrm{t} / \mathrm{ha}$ dan india 9,3 t/ha (FAO, 2009).
Rendahnya produktivitas cabai salah satunya karena keterbatasan teknologi budidaya yang diterapkan oleh petani, sementara dilain pihak telah banyak teknologi yang dihasilkan oleh instansi peneliatian maupun perguruan tinggi yang seharusnya dapat mendukung peningkatan produksi cabai di tingkat petani. Salah satu penyebab rendahnya produksi cabai di tingkat petani adalah karna masih sedikit petani yang menggunakan pupuk organik, penggunaan pupuk organic dapat memperbaiki struktur tanah, sehingga memberikan hasil produksi cabai yang maksimal, selain itu pupuk organik mudah diperoleh, harganya murah dan cara membuatnya juga mudah. Umumnya petani cenderung menggunakan pupuk kimia dengan dosis berlebihan, padahal dalam jangka waktu yang lama menimbulkan dampak negative berupa pemadatan tanah dan merusak ekosistem. Untuk itu penggunaan pupuk organic secara bijaksana perlu di kembangkan.

Diterbitkan Oleh, 
Kelebihan dari penggunaan pupuk organic adalah selain mengandung unsur hara makro juga terdapat unsur mikro yang tidak terdapat pada pupuk kimia. Pupuk organic juga ramah lingkungan dan mudah diperoleh bahkan dapat diproduksi sendiri oleh petani. Selain itu kemampuan pupuk organic memperbaiki sifat biologi tanah dapat meningkatkan aktivitas mikroorganisme sehingga dapat meningkatkan kesuburan tanah. Tanah yang keras akan menjadi gembur sehingga aerasi tanah akan lebih baik (Multazam,dkk,2014).

Hasil penelitian tentang penggunaan pupuk organic, sudah banyak dilakukan oleh lembagalembaga terkait, bahkan sudah dilakukan berbagai usaha untuk mendesiminasikan teknologi agar sampai di lahan petani.

Berbagai upaya yang dilakukan pemerintah, agar transfer teknologi ke petani dapat dilakukan secara luas, baik berupa penyuluhan maupun pelatihan guna meningkatkan pengetahuan petani. Salah satunya adalah desiminasii tentang penggunaan pupuk organic pada tanaman cabai.

Pengetahuan merupakan tahap awal terjadinya persepsi yang kemudian akan melahirkan sikap terhadap suatu teknologi yang diintroduksikan.

Dengan adanya pengetahuan atau wawasan baru akan mendorong pembentukan sikap yang akhirnya akan mendorong terjadinya perubahan perilaku. Suharyanto, dkk (2006) menyatakan bahwa sikap petani terhadap inovasi teknologi sangat tergantung dari pengetahuan dan pengalaman lapangan mereka. Pengetahuan yang baik tentang suatu hal akan mendorong terjadinya perubahan perilaku pada individu tersebut. Pengetahuan tentang manfaat suatu hal akan mengakibatkan seseorang bersikap positif, demikian pula sebaliknya. Sikap merupakan potensi pendorong yang ada pada individu untuk bereaksi terhadap lingkungan.

Sehubungan dengan dengan hal tersebut maka perlu dilakukan penelitian guna mendapatkan informasi dasar mengenai penggunaan pupuk organik dan tingkat pengetahuan, sikap dan perilaku petani terhadap penggunaan pupuk organic pada tanaman cabai.

\section{METODE PENELITIAN}

Penelitian dilaksanakan pada bulan Januari sampai Desember di kabupaten Jeneponto. Pemilihan lokasi dilakukan secara purposive dengan pertimbangan bahwa daerah tersebut merupakan daerah pengembangan cabai di Sulawesi Selatan. Penelitian dilakukan dengan menggunakan metode survai dan observasi langsung.

Jumlah responden sebanyak 60 orang yang dipilih secara acak sederhana (simple random sampling). Informasi berupa data primer diperoleh melalui wawancara dengan bantuan kuesioner terstruktur. Data primer yang dikumpulkan terdiri atas; (1) data aspek pengetahuan, sikap dan perilaku petani terhadap penggunaan pupuk organic; (2) sebagai data pendukung juga dikumpulkan informasi mengenai penggunaan pupuk pada tanaman cabai. Selain data primer juga dikumpulkan data sekunder dari instansi terkait atau dari laporan penelitian terdahulu.

Data yang telah dikumpulkan ditabulasi kemudian digolongkan berdasarkan jenis datanya. Data identitas responden disajikan dalam bentuk table dan penjelasan singkat. Sedangkan data berupa jawaban yang berhubungan dengan pengetahuan petani tentang pupuk organic, setiap jawaban diberi bobot nilai tertentu. Selanjutnya dibuat nilai scoring dari masing masing responden. Kemudian dibuat penggolongan yaitu (a) Pengetahuan rendah dengan nilai scoring $\leq 50,99$ $\%$;(b) Sedang dengan nilai scoring 51,00-80,99 \% dan (c) pengetahuan tinggi dengan scoring $\geq 81,00$ $\%$.Sikap petani digolongkan atas sikap (a) setuju; (b)ragu ragu; dan (c) tidak setuju; Sedangkan penggolongan terhadap perilaku adalah (a) rendah dengan nilai scoring $\leq 50,99 \%$, (b) sedang dengan nilai scoring $51,00-80,99 \%$; dan (c) tinggi dengan nilai scoring $\geq 81,00 \%$.

\section{HASIL DAN PEMBAHASAN}

\section{Gambaran Umum}

Kabupaten Jeneponto memiliki wilayah seluas $749,79 \mathrm{~km}^{2}$ dan secara administrasi terbagi menjadi 11 kecamatan. Iklim di Kabupaten Jeneponto tergolong kering di hampir semua kecamatan, kecuali kecamatan Kelara, Rumbia dan

Diterbitkan Oleh, 
sebagian kec. Bangkala yang tergolong agak basah. Musim hujan terjadi pada bulan November sampai April dan musim kemarau pada bulan Mei sampai Oktober

\section{Karakteristik Responden}

Umur

Salah satu faktor yang berpengaruh terhadap kemampuan fisik dan psikis seseorang adalah umur. Umur produktif memungkinkan seseorang secara fisik dan psikis optimal untuk bekerja. Sedangkan seseorang yang sudah memasuki masa tua, secara fisik relatif tidak sanggup lagi untuk bekerja dikategorikan sebagai umur yang tidak produktif. Berdasarkan data yang diperoleh, umur responden di Kabupaten Jeneponto mulai dari 22 - 65 tahun, untuk jelasnya dapat dilihat pada table 1 .

Tabel 1. Umur responden petani Cabai di Kab. Jeneponto,tahun 2015

\begin{tabular}{ccc}
\hline \multirow{2}{*}{ Umur (tahun) } & \multicolumn{2}{c}{ Kab. Jeneponto } \\
\cline { 2 - 3 } & $\begin{array}{c}\text { Jumlah responden } \\
\text { (org) }\end{array}$ & $\begin{array}{c}\text { Persentase } \\
(\%)\end{array}$ \\
\hline $22-39$ & 34 & 56,7 \\
$40-57$ & 25 & 41,7 \\
$\geq 58$ & 1 & 1,6 \\
Jumlah & 60 & 100.0 \\
\hline
\end{tabular}

Keterangan: Responden didominasi usia muda yaitu 22-39 tahun (56,7\%), Sedangkan responden yang berusia $\geq 58$ jumlahnya sangat sedikit $(1,6 \%)$

\section{Pendidikan}

Menurut Winkel (2006), tingkat pendidikan merupakan salah satu yang berpengaruh terhadap akseptabilitas perkembangan informasi dan teknologi seseorang. Semakin tinggi pendidikan semakin mudah seseorang tersebut untuk menyerap dan menerima informasi, dengan demikian akan berpengaruh terhadap adopsi teknologi dan fleksibel terhadap peluang dan tantangan yang dihadapi. Untuk jelasnya pendidikan responden dapat dilihat pada Tabel 2.

Tabel 2. Tingkat Pendidikan responden petani Cabai di Kab. Jeneponto tahun 2015

\begin{tabular}{ccc}
\hline & \multicolumn{2}{c}{ Jeneponto } \\
\cline { 2 - 3 } Tingkat Pendidikan & $\begin{array}{c}\text { Jumlah responden } \\
(\text { org })\end{array}$ & $\begin{array}{c}\text { Persentase } \\
(\%)\end{array}$ \\
\hline Tidak Tammat SD & 6 & 10.0 \\
SD & 35 & 58.3 \\
SMP & 12 & 20.0 \\
SMA & 7 & 11.7 \\
Jumlah & 60 & 100.0 \\
\hline
\end{tabular}

Keterangan: Responden umumnya berpendidikan lebih rendah (tidak tammat SD dan SD) Responden yang tidak tammat SD $(10 \%)$

\section{Pengalaman berusahatani Cabai}

Menurut Mardikanto (2013) pengalaman seorang petani berpengaruh dalam mengelola usahatani, petani yang memiliki pengalaman berusahatani lebih lama cenderung sangat selektif dalam proses pengambilan keputusan.

Diterbitkan Oleh, Unit Penelitian dan Pengabdian Masyarakat, Politeknik Pembangunan Pertanian Gowa http://ejournal.polbangtan-gowa.ac.id
Pengalaman berusahatani cabai responden di mulai dari 1 -20 tahun, Umumnya responden mempunyai pengalaman berusahatani sekitar 5-10 tahun (66,7\%) Tetapi masih dijumpai responden yang pengalamannya menanam cabai baru 2 tahun. Untuk jelasnya dapat dilihat pada table 3 . 
Tabel 3. Pengalaman Responden dalam Usahatani Cabai di Kab. Jeneponto tahun 2015

\begin{tabular}{ccc}
\hline \multirow{2}{*}{$\begin{array}{c}\text { Pengalaman Berusahatani Cabai } \\
\text { (tahun) }\end{array}$} & \multicolumn{3}{c}{ Jeneponto } \\
\cline { 2 - 3 } & $\begin{array}{c}\text { Jumlah responden } \\
(\text { org })\end{array}$ & $\begin{array}{c}\text { Persentase } \\
(\%)\end{array}$ \\
\hline$<5$ & 2 & 3.3 \\
$5-10$ & 40 & 66.7 \\
$>10$ & 18 & 30.0 \\
Jumlah & 60 & 100.0 \\
\hline
\end{tabular}

\section{Keikutsertaan dalam kelompok tani}

Keikutsertaan responden dalam kelompok tani umumnya sudah agak lama yaitu kisaran 5-8 tahun. Keikutsertaan pada kelompok tani yang terendah adalah 1 tahun dan yang tertinggi adalah 8 tahun. Untuk jelasnya dapat dilihat pada table 4.

\section{Luas lahan}

Umumnya luas lahan yang dimiliki petani cabai umumnya antara $0,5-1,5$ ha, dan hanya beberapa saja yang mempunyai lahan lebih dari 1,5 ha. Untuk jelasnya dapat dilihat pada tabel 5. Hal ini berarti responden harus memanfaatkan lahannya sebaik mungkin untuk mendapatkan hasil yang optimal. Salah satu cara yang bisa ditempuh adalah dengan memanfaatkan teknologi dalam usahataninya.

\section{Pola Tanam}

Pola tanam responden adalah jenis-jenis tanaman yang ditanam selama setahun. Pola tanam yang dominan dilakukan responden adalah CabeJagung dan Cabai - Jagung - Ubikayu, (dataran rendah). Sedangkan pola tanam Cabe - Kol, bawang merah, wortel adalah pola tanam pada daerah dataran tinggi. Untuk jelasnya dapat dilihat pada tabel 6.

Tabel 4. Keikutsertaan responden dalam kelompok tani di Kab. Jeneponto tahun 2015

\begin{tabular}{ccc}
\hline \multirow{2}{*}{$\begin{array}{c}\text { Keikutsertaan dalam kelompok } \\
\text { tani (th) }\end{array}$} & Jeneponto \\
\cline { 2 - 3 } & Jumlah responden & Persentase \\
$($ (org) & $(\%)$ \\
\hline 5 & 20 & 33.3 \\
$5-10$ & 40 & 66.7 \\
Jumlah & 0 & 0 \\
\end{tabular}

Tabel 5. Luas lahan responden di Kab. Jeneponto, tahun 2015

\begin{tabular}{ccc}
\hline Luas Lahan (ha) & \multicolumn{2}{c}{ Jeneponto } \\
\cline { 2 - 3 } & $\begin{array}{c}\text { Jumlah responden } \\
(\text { org })\end{array}$ & $\begin{array}{c}\text { Persentase } \\
(\%)\end{array}$ \\
\hline$<0,5$ & 7 & 11.7 \\
$0,5-0,9$ & 27 & 45.0 \\
$1,0-1,5$ & 23 & 38.3 \\
$>1,5$ & 3 & 5.0 \\
Jumlah & 60 & 100.0 \\
\hline
\end{tabular}

Diterbitkan Oleh, 
Tabel 6. Pola tanam responden dalam setahun di Kab. Jeneponto tahun 2015

\begin{tabular}{lcc}
\hline \multicolumn{1}{c}{ Pola Tanam } & $\begin{array}{c}\text { Jumlah Responden } \\
\text { (orang) }\end{array}$ & $\begin{array}{c}\text { Persentase } \\
(\%)\end{array}$ \\
\hline Cabai - Jagung & 20 & 33.3 \\
Cabai- Jagung- Ubikayu & 18 & 30.0 \\
Cabai - Jagung- Kacang Tunggak & 1 & 1.7 \\
Cabai - kol - bawang merah & 1 & 1.7 \\
Cabai - wortel & 4 & 6.7 \\
Cabai - bwg merah & 6 & 10.0 \\
Cabai - kol & 4 & 6.7 \\
Cabai - kacang tunggak & 3 & 5.0 \\
Cabai - kacang tanah & 1 & 1,7 \\
Cabai - tomat & 2 & 3.3 \\
\multicolumn{1}{c}{ Jumlah } & 60 & 100 \\
\hline
\end{tabular}

\section{Teknologi Exixting Petani}

Umumnya petani dalam usaha budidaya cabai, menggunakan teknologi seadanya, pengetahuan petani akan adanya introduksi teknologi masih kurang, sehingga perlu peranan desiminasi untuk mengsosialisasikan teknologi tersebut. Adapun teknologi budidaya cabai oleh petani dapat dilihat pada tabel 7 .

\section{Pengetahuan Responden tentang Pupuk Organik}

Pengetahuan adalah salah satu komponen perilaku petani yang turut menjadi faktor dalam adopsi inovasi. Tingkat pengetahuan petani mempengaruhi petani dalam mengadopsi pembaharuan atau perubahan, petani memerlukan pengetahuan mengenai aspek teoritis dan pengetahun praktis. Sebagai salah satu aspek dari perilaku, pengetahuan merupakan suatu kemampuan individu (petani) untuk mengingatingat segala materi yang dipelajari dan kemampuan untuk mengembangkan intelgensi (Sudijanto, 1978 dalam Sedana, 2010). Tingkat pengetahuan responden terhadap penggunaan Pupuk Organik di Kabupaten Jeneponto dapat dilihat pada Tabel 8.

Pada Tabel 8, dapat dilihat bahwa di Kabupaten Jeneponto tingkat pengetahuan responden pada umumnya $(65 \%)$ berada pada kategori sedang dengan skor nilai berkisar pada $51,00-80,99$. Pengetahuan tentang pupuk organic belum banyak diketahui oleh responden, mereka beranggapan bahwa pupuk organic adalah kotoran ternak kering tanpa fermentasi dan bisa langsung digunakan di lahan, atau disebut juga pupuk kandang.

Pengetahuan tentang manfaat pupuk organic telah banyak diketahui oleh responden. Pada umumnya responden telah mengetahui bahwa pupuk organic bermanfaat untuk menyuburkan tanah dan pada akhirnya dapat meningkatkan produksi tanaman baik dari segi kualitas maupun kuantitasnya. Responden juga mengetahui bahwa dalam pertanaman cabai diperlukan pupuk organik.

Pengetahuan tentang bahan yang bisa digunakan dalam pembuatan pupuk organic masih perlu ditingkatkan. Menurut seluruh responden (100\%) di kabupaten Jeneponto bahan yang bisa digunakan untuk pupuk organic hanya kotoran ternak. Pengetahuan tentang perlunya mikroorganisme dalam pembuatan pupuk organic masih belum banyak diketahui oleh responden. menurut responden (100\%) bahwa mereka belum pernah melakukan fermentasi dan belum mengetahui tentang decomposer tersebut. Pengetahuan tentang dosis pupuk organic pada tanaman cabai menurut sebagian besar responden, tidak perlu dosis tertentu karena semakin banyak pupuk organic semakin baik. Dalam mengaplikasikan pupuk organic di lahan, sebagian besar responden hanya menabur di atas lahan tanpa mencampur/diaduk dengan tanah, alasannya untuk menghemat tenaga kerja. 
Tabel 7. Teknologi existing petani cabai di Kab. Jeneponto tahun 2015

\begin{tabular}{cc}
\hline Teknologi & Cara Petani \\
\hline Penggunaan varietas & Tobak dan vanex (toko tani) \\
Jarak tanam & $30 \mathrm{~cm} \times 30 \mathrm{~cm}$ atau $35 \mathrm{~cm} 35 \mathrm{~cm}$ \\
Pemupukan & Urea, ZA dan NPK \\
Penggunaan Pupuk organik & Kurang \\
Penggunaan Mulsa & Tidak \\
Hama penyakit & lalat buah, ulat, layu, kerdil dan buah yang gugur \\
Pemberantasan Hama Penyakit & Semprot obat-obatan kimia \\
\hline
\end{tabular}

Tabel 8. Tingkat pengetahuan responden terhadap penggunaan pupuk organik di Kab. Jeneponto, tahun 2015.

\begin{tabular}{cccc}
\hline \multirow{2}{*}{$\begin{array}{c}\text { Kategori Tingkat } \\
\text { Pengetahuan }\end{array}$} & Skor & \multicolumn{2}{c}{ Jeneponto } \\
\cline { 3 - 4 } & & $\begin{array}{c}\text { Jumlah responden } \\
\text { (org) }\end{array}$ & $\begin{array}{c}\text { Persentase } \\
(\%)\end{array}$ \\
\hline Rendah & $\leq 50,99$ & 10 & 16.67 \\
Sedang & $51,00-80,99$ & 39 & 65.00 \\
Tinggi & $\geq 81,00$ & 11 & 18.33 \\
Jumlah & & 60 & 100.0 \\
\hline
\end{tabular}

Waktu pengaplikasian pupuk organic telah diketahui oleh sebagian besar responden yaitu sebelum dilakukan penanaman biasanya seminggu atau sepuluh hari sebelum tanam. Pengetahuan tentang pupuk organic cair masih sedikit diketahui oleh responden.

\section{Sikap Responden Terhadap Penggunaan Pupuk Organik}

Sikap dikatakan sebagai suatu respon evaluatif. Respon hanya akan timbul apabila individu dihadapkan pada suatu stimulus yang menghendaki adanya reaksi individual. Respon evaluatif berarti bahwa bentuk reaksi yang dinyatakan sebagai sikap, timbulnya didasari oleh proses dalam diri individu yang memberi kesimpulan terhadap stimulus dalam bentuk nilai baik-buruk, positifnegatif, menyenangkan-tidak menyenangkan, yang kemudian mengkristal sebagai potensi reaksi terhadap objek sikap (Azwar, 2009).

Sikap adalah pernyataan setuju, ragu-ragu atau tidak setuju dengan hal-hal yang berkaitan dengan pupuk organic. Sikap responden terhadap penggunaan pupuk organic di Kabupaten Jeneponto dapat dilihat pada Tabel 9.

Tabel 9. Sikap responden terhadap penggunaan pupuk organik di Kab. Jeneponto, tahun 2015.

\begin{tabular}{cccc}
\hline \multirow{2}{*}{ Kategori Sikap } & \multirow{2}{*}{ Skor } & \multicolumn{2}{c}{ Jeneponto } \\
\cline { 3 - 4 } & & $\begin{array}{c}\text { Jumlah responden } \\
(\text { org })\end{array}$ & $\begin{array}{c}\text { Persentase } \\
(\%)\end{array}$ \\
\hline Rendah & $\leq 50,99$ & 4 & 6.67 \\
Sedang & $51,00-80,99$ & 34 & 56.67 \\
Tinggi & $\geq 81,00$ & 22 & 36.66 \\
Jumlah & & 60 & 100.0 \\
\hline
\end{tabular}

Pada tabel 9 dapat dlihat bahwa sikap responden terhadap penggunaan pupuk organic pada umumnya berada pada kategori sedang $(56,67 \%)$. Pada umumnya responden menyetujui pernyataan bahwa pupuk organic dapat menyuburkan tanah dan sebagai sumberhara bagi tanaman. Responden juga menyatakan setuju dengan pernyatan bahwa kotoran hewan, sisa-sisa

Diterbitkan Oleh, 
pangkasan daun, sisa tanaman, sampah basah rumah tangga dapat dibuat pupuk organic. Hanya sedikit yang tidak setuju, karena menganggap hanya kotoran ternak yang bisa digunakan untuk bahan pupuk organik. Pernyataan bahwa Selain pupuk organic dalam bentuk padat juga terdapat pupuk organic dalam bentuk cair dijawab oleh sebagian besar responden dengan ragu-ragu karena mereka belum tahu tentang pupuk organic cair.

Pernyataan bahwa pemberian pupuk organik sebaiknya diberikan sebelum tanam sehingga pada saat penanaman tanah sudah gembur, disetujui oleh sebagian besar responden. Pernyataan bahwa pemberian pupuk organic padat pada tanam cabai sebaiknya dilakukan dengan cara membenamkannya dalam tanah, sebagian besar tidak setuju bila dibenamkan, alasannya hal itu memerlukan tenaga kerja.

Pernyataan bahwa pemberian pupuk organic pada cabai dapat meningkatkan produksi dan kualitas hasil disetujui oleh sebagian besar responden .Pernyataan bahwa pemberian pupuk organic pada cabai merupakan salah satu komponen dalam pengendalian hama penyakit, hampir seluruh responden menjawab dengan ragu- ragu atau tidak setuju. Alasannya mereka tidak paham dengan hal tersebut. Pernyataan bahwa pemberian pupuk organic dapat memperbaiki struktur tanah sehingga tanah menjadi gembur, disetujui oleh hampir semua responden.

\section{Perilaku Responden Terhadap Penggunaan Pupuk Organik}

Sarwono (1999) mengemukakan bahwa perilaku dapat ditentukan oleh sikap jika sikap muncul atau dimunculkan dalam kesadaran seseorang. Selanjutnya juga dikatakan bahwa perilaku akan lebih sesuai dengan sikap yang sesungguhnya jika situasinya memang menghendaki hal yang demikian.

Perilaku responden dalam penggunaan pupuk organic di Kabupaten Jeneponto dapat dilihat pada table 10 .

Pada table 10 dapat dilhat bahwa perilaku responden yang berkaitan dengan penggunaan pupuk organic dominan berada pada kategori sedang. Hal ini berarti bahwa di kabupaten Jeneponto masih banyak responden yang belum mengaplikasikan pupuk organic dalam pertanaman cabainya.

Tabel 10. Perilaku responden terhadap penggunaan pupuk organik di Kab. Jeneponto, tahun 2015.

\begin{tabular}{cccccc}
\hline Kategori & \multirow{2}{*}{ Skor } & \multicolumn{2}{c}{ Jeneponto } & \multicolumn{2}{c}{ Maros } \\
\cline { 3 - 6 } Perilaku & & $\begin{array}{c}\text { Jumlah } \\
\text { responden (org) }\end{array}$ & $\begin{array}{c}\text { Persentase } \\
(\%)\end{array}$ & $\begin{array}{c}\text { Jumlah responden } \\
(\text { org })\end{array}$ & $\begin{array}{c}\text { Persentase } \\
(\%)\end{array}$ \\
\hline Rendah & $\leq 50,99$ & 27 & 45.00 & 2 & 3.33 \\
Sedang & $51,00-80,99$ & 31 & 51.67 & 38 & 63.33 \\
Tinggi & $\geq 81,00$ & 2 & 3.33 & 20 & 33.33 \\
Jumlah & & 60 & 100.0 & 60 & 100.0 \\
\hline
\end{tabular}

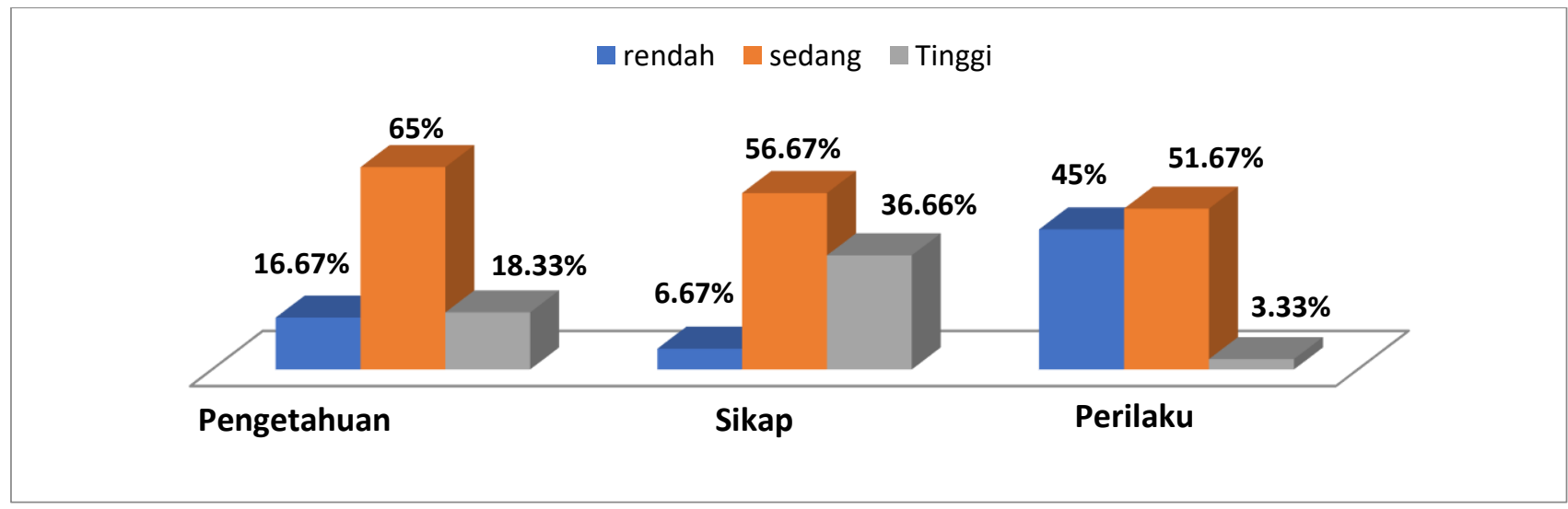

Gambar 1. Tingkat pengetahuan, Sikap dan perilaku responden di Kab. Jeneponto

Diterbitkan Oleh,

Unit Penelitian dan Pengabdian Masyarakat, Politeknik Pembangunan Pertanian Gowa

http://ejournal.polbangtan-gowa.ac.id 
Responden di Jeneponto masih sedikit yang menggunakan pupuk organic. Responden umumnya menggunakan kotoran ternak kering tanpa fermentasi. Bahkan beberapa reponden samasekali tidak menggunakan pupuk kandang dan hanya menggunakan pupuk kimia. Perilaku Pemberian pupuk organic dilakukan sebelum tanam setelah pengolahan tanah dengan dosis tertentu, dilakukan oleh sebagian besar responden. Demikian pula dengan perilaku pemberian pupuk organic dilakukan dengan cara membenamkan atau mencampurkan dengan tanah sebelum penanaman.

\section{Tingkat Pengetahuan, Sikap dan Perilaku Responden Terhadap Penggunaan Pupuk Organik di Kabupaten Jeneponto}

Tingkat pengetahuan, Sikap dan Perilaku responden terhadap penggunaan pupuk organic di kabupaten Jeneponto dapat dilihat pada Gambar 1. Pada Gambar 1 terlihat bahwa Tingkat pengetahuan, Sikap dan perilaku responden di Kabupaten Jeneponto umumnya berada pada kategori sedang, artinya umumnya pengetahuan petani akan penggunaan pupuk organic berada dalam kategori sedang, demikian pula diiringi dengan sikap dan perilakunya dalam menggunakan pupuk organic. Olehnya itu perlunya dilakukan desiminasi teknologi budidaya cabai, terutama penggunaan pupuk organic, manfaat, dosis dan cara menggunakannya kepada petani, desiminasi ini dapat dilakukan dalam bentuk demonstrasi plot, dengan melibatkan dan menjadi pelaku adalah petani, dimana petani sendiri yang melakukan dengan didampingi oleh para penyuluh lapangan. Tingkat Pengetahuan, Sikap, dan Perilaku responden terhadap penggunaan pupuk organic di Kabupaten Jeneponto

\section{KESIMPULAN}

1. Responden di kabupaten Jeneponto sebagian besar belum menggunakan pupuk organik dalam melaksanakan budidaya cabai.

2. Tingkat Pengetahuan responden tentang pupuk organik di Kabupaten Jeneponto umumnya berada pada kategori sedang $(65 \%)$.
3. Sikap responden terhadap pupuk organik di Kabupaten Jeneponto umumnyaberada pada kategori sedang $(56,67 \%)$.

4. Perilaku responden terhadap penggunaan pupuk organik di Kabupaten Jeneponto umumnya termasuk kategori sedang $(51,67 \%)$.

\section{DAFTAR PUSTAKA}

Anonimous, Statistik Dalam Angka, BPS Sulawesi Selatan 2015

Ardi. D.R. dan R.D.M. Simanungkalit. 2006. Pupuk Organik dan Pupuk Hayati. Balai Besar Penelitian dan Pengembangan Sumber daya Lahan Pertanian. Badan Litbang Pertanian.

Azwar, S. 2009. Sikap Manusia Teori dan Pengukurannya. Pustaka Pelajar. Yogyakarta.

Mar'at. 1984. Sikap Manusia Perubahan Serta Pengukurannya. Jakarta. Ghalia Indonesia.

Multazam Ainun, Agus Suryanto dan Ninuk Herlina, 2014. Pengaruh Macam Pupuk Organik dan Mulsa Pada Tanaman Brocoli. Jurnal Produksi Tanaman Vol.2. No.2.

Rahmat, J. 2000. Psikologi Komunikasi. Rosda Karya. Bandung.

Santoso, S. 2005. SPSS Versi 14. Mengolah data Statistik secara Profesional. Jakarta. PT Elex Media Komputindo Kelompok Gramedia.

Sarwono, SW. 2000. Psikologi Sosial Individu dan Teori-Teori Psikologi Sosial. Jakarta. Balai Pustaka.

Sedana, G. 2008. Hubungan Antara Sikap dan Pengetahuan Petani Mengenai Fermentasi Biji Kakao (Kasus di Subak-abian Asagan, Kecamatan Selemadeg Timur, Kabupaten Tabanan). gedesedena.wordpress.com. Diakses tanggal 15 September 2014.

Suharyanto, Rubiyo, Rinaldi J. 2006. Pengetahuan, Sikap dan Perilaku Petani Terhadap Hama Penggerek Buah Kakao (Pbk) Conopomorpha cramerella Snellen di Kabupaten Tabanan Bali. http://ntb.litbang .deptan.go.id. (2 September 2010) 
Winkel WS. 2006. Psikologi pengajaran. Jakarta : Penerbit PT. Gramedia

Yusmasari, 2003. Perilaku Komunikasi Masyarakat Terhadap Manfaat dan
Pelestarian Mangrove di Desa Pematang Pasir Kecamatan Ketapang, Lampung Selatan. Tesis. Bogor. Program Pascasarjana Institut Pertanian Bogor. 